\title{
Fluktuasi Ikan Karang di Kawasan Konservasi Laut Daerah Gili Sulat dan Gili Lawang, Lombok Timur, Nusa Tenggara Barat
}

\author{
Diaz Adiyoga*, Retno Hartati, Wilis Ari Setyati \\ Departemen Ilmu Kelautan, Fakultas Perikanan dan Ilmu Kelautan, Universitas Diponegoro \\ Jl. Prof.H.Soedarto S.H, Tembalang,Semarang, Jawa Tengah 50275 Indonesia \\ *Corresponding author, e-mail: dtadiyoga@gmail.com
}

\begin{abstract}
ABSTRAK: Keanekaragaman ekosistem pesisir dan laut yang terdapat di Gili Sulat Gili Lawang merupakan salah satu sumberdaya yang penting untuk dilindungi mengingat besarnya ketergantungan masyarakat terhadap ekosistem tersebut. Ekosistem terumbu karang adalah salah satu ekosistem penting di Gili Sulat dan Gili Lawang yang menjadikan ikan dan biota lainnya sebagai tempat tinggal maupun mencari makan. kondisi terumbu karang sangat mempengaruhi kekayaan dan kelimpahan ikan karang. Jika kondisi terumbu karang baik maka kelimpahan ikannya tinggi, begitu pula sebaliknya. Penelitian kelimpahan ikan karang dilakukan pada 14-21 November 2018 di Kawasan Konservasi Laut Daerah Gili Sulat dan Gili Lawang. Pengambilan data menggunakan metode sensus visual untuk ikan karang di kedalaman 8-10 meter dengan 3 buah transek sepanjang 50 meter sejajar dengan garis pantai. Berdasarkan hasil penelitian yang dilakukan di Kawasan Konservasi Laut Daerah Gili Sulat dan Gili Lawang kelimpahan ikan karang, rata - rata nilai kelimpahan ikan karang di zona pemanfaatan paling tinggi yaitu $621 \mathrm{ind} / \mathrm{ha}$, paling rendah pada zona inti sebesar $615 \mathrm{ind} / \mathrm{ha}$ dan zona perikanan berkelanjutan sebesar $616 \mathrm{ind} / \mathrm{ha}$
\end{abstract}

Kata Kunci: Ikan karang; KKLD; Gili Sulat; Gili Lawang; Kelimpahan

\section{Abundance of Reef Fishes in The Gili Sulat and Gili Lawang Marine Protected Area, East Lombok, West Nusa Tenggara}

\begin{abstract}
The diversity of coastal and marine ecosystems found on Gili Sulat Gili Lawang is one of the important resources to protect given the large dependence of the community on these ecosystems. The coral reef ecosystem is one of the important ecosystems on Gili Sulat and Gili Lawang which makes fish and other biota as a place to live or find food. the condition of coral reefs greatly affects the wealth and abundance of reef fish. This research was conducted in November 14-21, 2018. Collecting data of reef fishes abundance using visual census method in 8-10 meter depth, use 3 pieces line transect with 50 meters long an roll out the transect along the shoreline. Based on the results of research conducted in Gili Sulat and Gili Lawang the Marine Protected Area reef fish abundance, the average abundance of reef fish in the utilization zone is highest at 621 ind / ha, the lowest in the core zone is 615 ind / ha and the fishing zone sustainable of 616 ind / ha
\end{abstract}

Keywords : Reef Fishes; Gili Sulat; Gili Lawang; Marine Protected Area; Abundance

\section{PENDAHULUAN}

Ikan karang adalah kelompok taksa ikan yang kehidupannya berasosiasi dengan lingkungan ekosistem terumbu karang (Hallacher, 2003). Ikan karang mempunyai hubungan yang erat dengan terumbu karang. Berbagai jenis ikan karang dan biota lainnya menjadikan terumbu karang sebagai tempat berlindung (shelter), tempat untuk mencari makan (feeding ground), tempat berkembang biak (spawning ground), dan sebagai daerah asuhan (nursery ground) (Muhlis, 2009). Allen dan Adrim (2003) menyatakan bahwa dari perkiraan 12.000 spesies ikan laut dunia, kurang lebih 7.000 spesies $(58,3 \%)$ merupakan ikan yang hidup pada daerah terumbu karang. Salah satunya Provinsi Nusa Tenggara Barat (NTB) merupakan bagian dari segitiga karang dunia (coral triangle) dengan kekayaan biodiversitas yang tinggi (Allen 2007). Berdasarkan potensi 
sumberdaya laut yang ada di kawasan Nusa Tenggara Barat, maka Pemerintah daerah berinsiatif untuk mengelola kawasan konservasi laut untuk melindungi kekayaan dan keanekaragaman hayati laut secara bertahap dan efektif di dua lokasi yaitu Gili Sulat dan Gili Lawang.

Gili Sulat dan Gili Lawang ditetapkan sebagai Kawasan Konservasi Laut Daerah (KKLD), sesuai dengan SK Bupati No. 188.45/452/KP/2004, tanggal 16 September 2004. KKLD tersebut diarahkan untuk daerah perlindungan laut dan taman wisata laut atau bahari. Keanekaragaman ekosistem pesisir dan laut yang terdapat di Gili Sulat Gili Lawang merupakan salah satu sumberdaya yang penting untuk dilindungi mengingat besarnya ketergantungan masyarakat terhadap ekosistem tersebut, namun beberapa permasalahan yang muncul di wilayah Lombok Tengah, Lombok Timur dan Sumbawa, Sumbawa Barat penggunaan potassium, bom dan racun banyak dilakukan (Ningtias et al., 2013; Rafandi et al., 2017). Ancaman tersebut berakibat rusaknya ekosistem terumbu karang. Pada umumnya keberadaan dan kondisi terumbu karang sangat mempengaruhi kekayaan dan kelimpahan ikan karang. Jika kondisi terumbu karang baik maka kelimpahan ikannya tinggi, begitu pula sebaliknya, jika kondisi terumbu karang buruk maka kelimpahan ikannya rendah. Fungsi terumbu karang yang kompleks tidak didukung oleh daya tahan terhadap kerusakan yang diakibatkan oleh aktivitas alam dan manusia.Tujuan penelitian ini adalah mengetahui jenis jenis serta komposisi ikan karang dan mengetahui pengaruh zonasi terhadap kelimpahan ikan karang di KKLD Gili Sulat dan Gili Lawang

\section{MATERI DAN METODE}

Penentuan lokasi penelitian dilakukan dengan metode purposive sampling terlebih yang ditujukan untuk ekosistem terumbu karang. Metode purposive sampling atau metode pertimbangan adalah teknik penentuan sampel dengan pertimbangan tertentu (Sugiyono, 2005). Pertimbangan tertentu seperti karakteristik lokasi berguna bagi pengamat untuk mendapatkan informasi yang relevan dan kemudahan mengunjungi kembali lokasi pemantauan yang sama. Karakteristik lokasi juga berfungsi sebagai sumber data pada saat dilakukan analisa. Pertimbangan lokasi penelitian ini berdasarkan zonasi yang dikeluarkan Dinas Kelautan dan Perikanan Lombok Timur yang kemudian dibagi menjadi zona inti, zona perikanan berkelanjutan dan zona pemanfaatan. (Gambar 1).

\section{Pengambilan Data Ikan Karang}

Pengambilan data kelimpahan ikan karang menggunakan metode sensus visual (Visual Census Method) menurut English et al. (1997) yang secara teknis dilakukan dengan metode

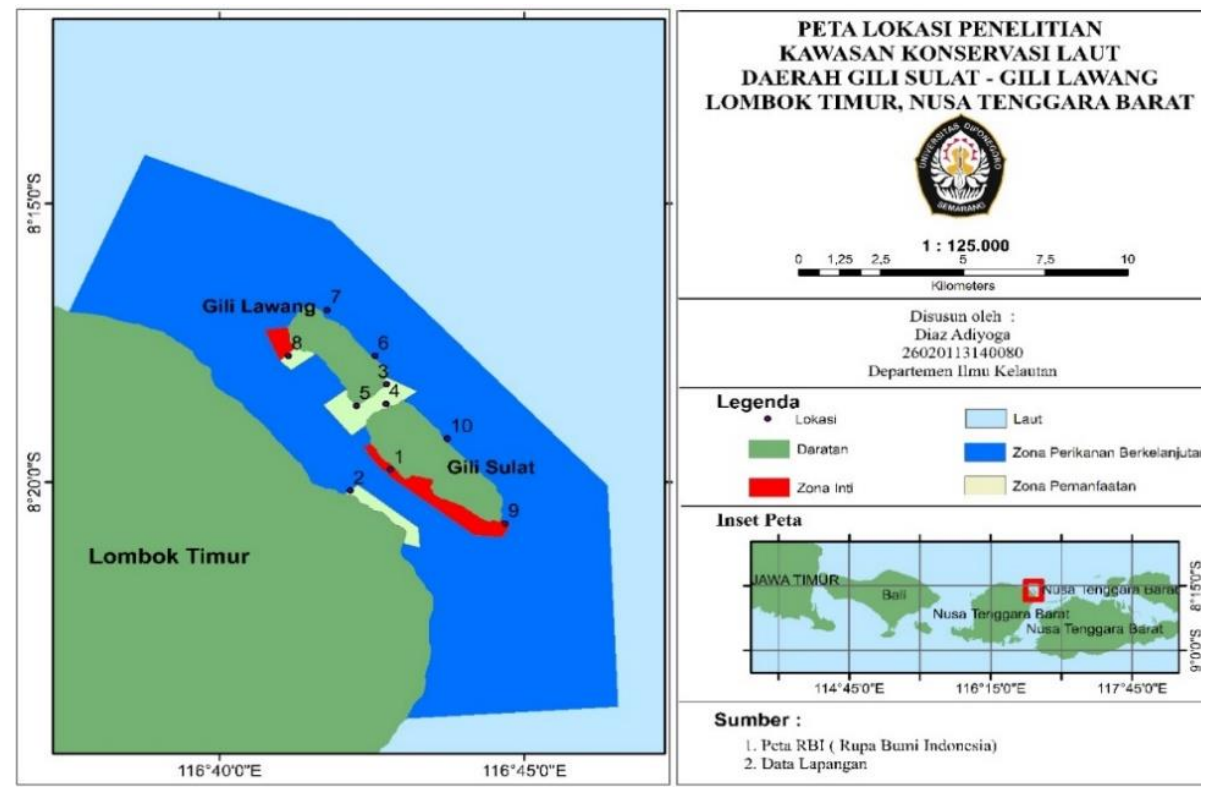

Gambar 1. Peta Lokasi Penelitian 
transek sabuk (belt transect). Parameter ekologis ikan karang yang diamati adalah keragaman jenis (jumlah jenis ikan dalam suatu lokasi), kelimpahan (dalam satuan jumlah per hektar). Pengamatan ini menggunakan tiga transek dengan panjang 50 meter serta lebar 5 meter (untuk ikan ukuran $>10 \mathrm{~cm}$ ) dan lebar 2 meter (untuk ikan ukuran $\leq 10 \mathrm{~cm}$ ). Transek diletakan sejajar sepanjang garis pantai (Yulianto et al., 2012). Pengambilan data dilakukan sebanyak tiga kali pengulangan. Analisis kelimpahan ikan karang yang berada di terumbu karang buatan dihitung dengan menggunakan rumus menurut Odum (1971).

\section{HASIL DAN PEMBAHASAN}

Wilayah Kawasan Konservasi Laut Daerah Gili Sulat-Gili Lawang terbagi menjadi 3 zona yaitu zona inti, zona pemanfaatan dan zona perikanan berkelanjutan. Setiap zona memiliki peranan tersendiri, zona inti ditujukan untuk menjaga kondisi ekosistem didalamnya, zona pemanfaatan diperuntukan untuk pemanfaatan wisata maupun budidaya dan zona perikann berkelanjutan diperuntukan untuk kegiatan penangkapan ikan secara berkelanjutan

Ikan karang merupakan salah satu organisme yang berperan penting dalam ekosistem terumbu karang, baik dalam keanekaragaman maupun morfologinya. Rata - rata nilai kelimpahan ikan karang di zona pemanfaatan paling tinggi yaitu 621 ind/ha, paling rendah pada zona inti sebesar $615 \mathrm{ind} / \mathrm{ha}$ dan zona perikanan berkelanjutan sebesar $616 \mathrm{ind} / \mathrm{ha}$ (Gambar 2). Nilai ratarata kelimpahan ikan karang setiap zonasi didapatkan dari hasil perhitungan total kelimpahan setiap stasiun dibagi dengan jumlah stasiun perzonasinya

Ikan karang merupakan kelompok taksa ikan yang kehidupannya berasosiasi dengan terumbu karang (Hallacer, 2003). Berdasarkan hasil penelitian didapatkan sebanyak 174 spesies ikan karang yang tergolong dalam 28 famili pada Kawasan Konservasi Laut Daerah (KKLD) Gili Sulat-Gili Lawang. Hasil ini berbeda jauh dengan penelitian Arifin dan Yulianda (2004) yang menemukan 19 famili di KKLD Gili Sulat-Gili Lawang. Hal ini menunjukkan bahwa tekanan konservasi di zona inti berpengaruh dalam kelimpahan ikan karang secara keseluruhan. Sesuai dengan Ardiwijaya et al., (2010) yang menjelaskan bahwa penurunan nilai kelimpahan ikan karang sangat dipengaruhi oleh beberapa faktor alam, antara lain kerusakan habitat, daya pulih ekosistem, dan juga tekanan perikanan. Aktivitas perikanan tangkap di zona inti, zona pemanfaatan dan zona perikanan berkelanjutan diduga menyebabkan penurunan kelimpahan ikan di wilayah tersebut. Sehingga diduga pengaruh zonasi tidak berpengaruh pada jenis ikan karang dan kelimpahan ikan karang

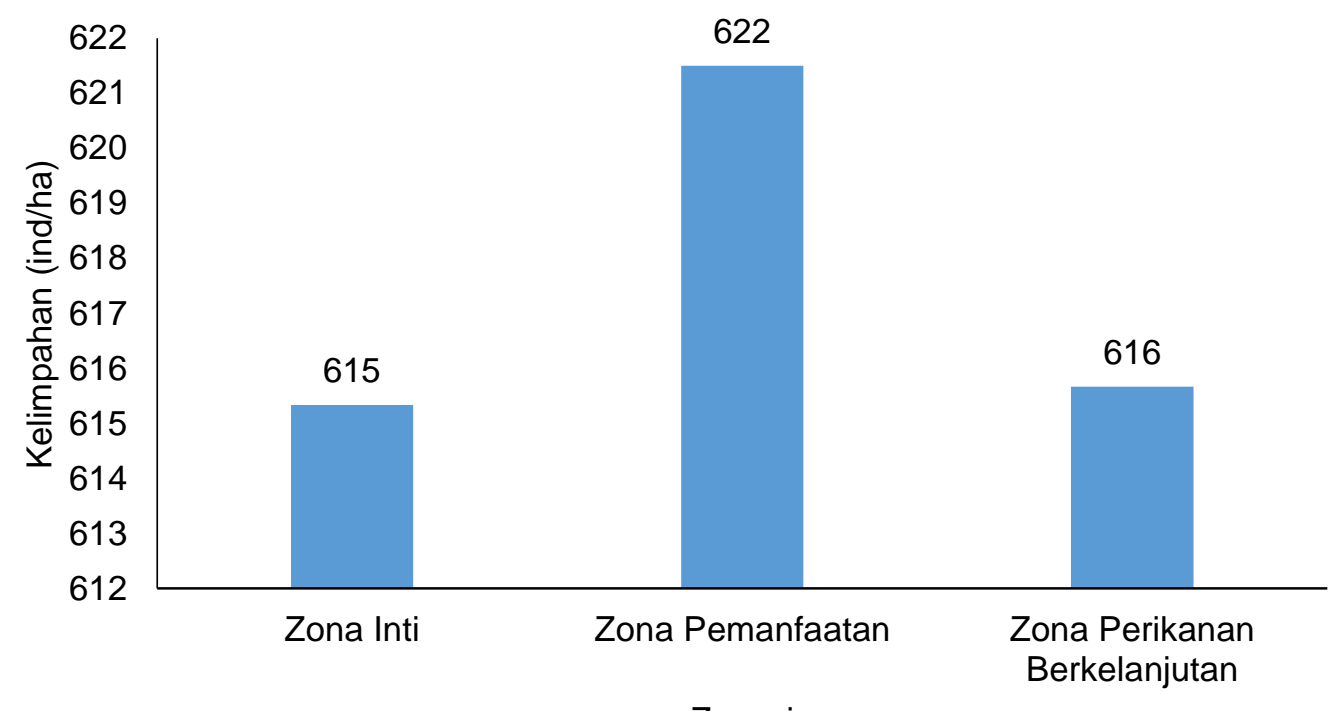

Zonasi

Gambar 2. Rata-rata Kelimpahan Ikan Karang di KKLD Gili Sulat-Gili Lawang 
Secara keseluruhan hasil kelimpahan jenis ikan didominasi oleh ikan Pomacentridae sebanyak $1636 \mathrm{ind} / \mathrm{ha}$ di zona inti, $1496 \mathrm{ind} / \mathrm{ha}$ di zona pemanfaatan dan 1597 ind/ha di zona perikanan, Pomacentridae adalah termasuk dalam ikan mayor, sehingga banyak ditemukan dii ekosistem terumbu karang. Menurut Runtuboi et al. (2018), bahwa ikan jenis Pomacentridae merupakan ikan dengan kelimpahan terbanyak dan merupakan ikan penetap (resident species) yang memiliki tingkah laku teritorial dan jarang berkeliaran jauh dari sumber makanan dan tempat berlindungan. Tingginya nilai kelimpahan dari famili Pomacentridae disebabkan juga oleh setiap stasiun penelitian terdapat jenis karang yang bercabang, sehingga kelimpahan ikan jenis Pomacentridae cenderung tinggi, karena ikan jenis ini menyukai hidup di daerah karang karang bercabang

Kelompok ikan target dari famili Caesionidae sebanyak 1900 ind/ha di zona inti, 1963 ind/ha di zona pemanfaatan dan di zona perikanan tidak ditemukan. Diduga di zona perikanan tidak ditemukan karena faktor dari daya jelajah ikan Caesionidae sangat luas. Menurut Allen (2000), famili Caesionidae yang merupakan jenis ikan pelagis yang merupakan perenang aktif, memiliki daya jelajah yang tinggi untuk mencari makan. Famili ini juga sering ditemukan bergerombol pada siang hari ketika sedang makan zooplankton pada pertengahan perairan diatas terumbu.

Ikan kelompok herbivora dari famili Acanthuridae sebanyak 858 ind/ha di zona inti, 928 ind/ha di zona pemanfaatan dan 1070 ind/ha di zona perikanan berkelanjutan Scarini/Scaridae sebanyak 852 ind/ha di zona inti, $699 \mathrm{ind} / \mathrm{ha}$ di zona pemanfaatan dan $709 \mathrm{ind} / \mathrm{ha}$ di zona perikanan. Ikan famili Labridae sebanyak $235 \mathrm{ind} / \mathrm{ha}$ di zona inti, $204 \mathrm{ind} / \mathrm{ha}$ di zona pemanfaatan dan $229 \mathrm{ind} / \mathrm{ha}$ di zona perikanan. Ketiga famili ini merupakan famili yang mendominasi hampir disetiap stasiun penelitian. Hal ini sesuai oleh Sale (1991) yang mengatakan komposisi dari ketiga famili ikan tersebut merupakan komposisi jenis yang selalu ditemukan paling banyak pada ekosistem terumbu karang. Menurut Green \& Bellwood (2009), ikan Acanthuridae merupakan ikan yang sering dijumpai dalam keadaan berkelompok, menjadikan Acanthuridae sebagai ikan herbivora yang mampumengontrol pertumbuhan alga. Hal yang menarik dalam penelitian ini yaitu banyak ditemukan ikan herbivora seperti Acanthuridae, Siganidae, Scarini/Scaridae pada setiap zonasinya. Diduga hal ini dapat terjadi karena ketersediaan makanan bagi ikan tersebut melimpah disetiap zonasinya. Berdasarkan hasil tutupan subtrat rata-rata alga yang paling mendominasi sehingga banyak terdapat ikan herbivora. Menurut Green \& Bellwood (2009), adanya pengaruh dari kehadiran ikan herbivora terhadap presentase tutupan alga pada suatu perairan.

Ikan indikator juga banyak ditemukan seperti ikan Chaetodontidae 720 ind/ha di zona inti, 565 ind/ha di zona pemanfaatan dan 567 ind/ha di zona perikanan. Kehadiran ikan indikator merupakan indikator ekosistem terumbu karang masih dalam keadaan stabil, namun apabila ikan indikator berkurang maka ekosistem terumbu karang sedang mengalami kerusakan. Laikun et al. (2014) menyatakan bahwa ikan famili Chaetodontidae dijadikan spesies indikator didasarkan pada preferensi yang kuat terhadap karang batu sebagai komponen utama penyusun terumbu karang.Berdasarkan penelitian Titaheluw (2015), tutupan terumbu karang meningkat berkorelasi positif dengan ikan Chaetodontidae .Sehingga dapat dikatakan semakin besar persentase tutupan karang hidup, semakin tinggi jumlah Chaetodontidae. Peningkatan jumlah karang hidup tersebut akan berdampak pada ketersediaan jumlah makanan ikan Chaetodontidae yang melimpah. Dimana persentase tutupan karang yang baik akan berdampak pada semakin banyak polip karang yang hidup sehingga persediaan makanan akan berlimpah.

Berdasarkan hasil yang didapatkan keragaman ikan di Gili Sulat-Gili Lawang cukup tinggi. Menurut Allen \& Steene (1994), jenis ikan karang yang banyak mendominasi terumbu karang adalah I0 kelompok ikan, yaitu Pomacentridae (Damselfishes), Labridae (Wrasses), Chaetodontidae (Butterflyfishes), Pomacanthidae (Angelfishes), Apogonidae (Cardinalfishes), Serranidae (Grouper \& Basslets), Scaridae (Parrotfishes), Acanthuridae (Surgeonfishes), Bleenidae (Blennies), dan Gobiidae (Gobies). Menurut Arifin dan Yulianda (2004), pola penyebaran ikan pada ekosistem terumbu sangat dipengaruhi oleh kondisi ekosistem terumbu karang, misalnya pada daerah terlindung dan terbuka, jenis-jenis ikan yang dijumpai akan berbeda. Kedalaman dan tipe substrat juga berpengaruh tehadap distribusi ikan karang.

Menurut Rani et al., (2009), ikan karang merupakan salah satu komunitas pada ekosistem terumbu karang yang berperan penting dalam aliran energi dan menjaga kestabilan ekosistem. Sebaran ikan karang sangat ditentukan oleh kondisi dan variasi habitat terumbu karang. Variasi habitat terumbu karang, dalam hal ini variasi mikro-habitat tidak hanya terdiri dari habitat karang saja, tetapi 
juga daerah berpasir, berbagai teluk dan celah, daerah algae dan sponge serta masih banyak lagi. Keberagaman habitat tersebut merupakan salah satu faktor kunci tingginya keragaman spesies ikan di terumbu karang sehingga habitat yang beranekaragam ini dapat menerangkan jumlah ikan-ikan karang pada ekosistem tersebut. Penurunan kondisi terumbu karang baik oleh faktor alam maupun antropogenik juga dengan sendirinya akan memengaruhi distribusi dan sebaran ikan karang dalam suatu area terumbu.

\section{KESIMPULAN}

Berdasarkan penelitian yang telah dilakukan, bahwa terdapt 174 spesies ikan yang ditemukan dan komposisi jenisnya didominasi oleh Pomacentridae rata-rata kelimpahan ikan karang tertinggi yaitu pada zona perikanan berkelanjutan sebesar 622 ind/ha, disusul pada zona pemanfatan sebesar $616 \mathrm{ind} / \mathrm{ha}$ dan zona inti sebesar $615 \mathrm{ind} / \mathrm{ha}$. Zonasi tidak begitu berpengaruh terhadap kelimpahan ikan karang

\section{DAFTAR PUSTAKA}

Allen, G.R. \& Steane, R. 1994. Indo-Pacific Coral reef Field Guide. Tropical Reef Research. Singapore.

Allen, G. 2000. Marine Fishes of South East Asia. Western Australian Museum, 2000.

Allen, G.R., \& Adrim, M. 2003. Coral Reef Fishes of Indonesia. Zoological Studies, 42(1): 1-72.

Allen, G.R. 2007. Conservation hotspots of biodiversity and endemism for Indo-Pacific coral reef fishes. Aquatic Conservation: Marine and Freshwater Ecosystems, 18: 541-556. doi: 10.1002/aqc.880

Ardiwijaya, R.L., Muttaqin, E. \& Herdiana, Y. 2010. Monitoring Coral Reef Ecological Assessment, Aceh 2010. Wildlife Conservation Society Marine Program Indonesia. Bogor, Indonesia.

Arifin, M. \& Yulianda. 2004. Keanekaragaman Ikan Karang di Perairan Lombok Timur, Nusa Tenggara Barat. Jurnal Iktiologi Indonesia, 3(1):19-26. doi: 10.32491/jii.v3i1.268

English, S.C., Wilkinson, V., \& Baker. 1997. Survey Manual for tropical Marine Resources. ASEAN-Australia Marine Science Project: Living Coastal Resources, Australian Institut of Marine Science

Green, A.L. \& Bellwood, D.R. 2009. Monitoring functional groups of herbivorous reef fishes as indicator of coral resilience - A practical guide for coral reef managers in the Asia Pacific Region. IUCN Working Group on Climate Change and Coral Reefs. IUCN, Gland, Switzerland.70p.

Hallacher, L.E. 2003. The ecology of coral reef fishes. University of Hawai

Laikun, J., Ari, B., Rondonuwu, \& Unstain, N.W.J. Rembet. 2014. Kondisi Ikan Karang Famili Chaetodontidae di Daerah Laut Perlindungan Desa Bahoi Kecamatan Likupang Barat Kabupaten Minahasa Utara. Jurnal IImiah Platax, 2(3):92-98. doi : 10.35800/jip.2.3.2014.9121

Muhlis. 2009. Ekosistem Terumbu Karang dan Kondisi Oseanografi Perairan Kawasan Wisata Bahari Lombok. Berkala Panelitian Hayati, 26:111-118

Ningtias, P., Kartawijaya, T., Yulianto, I., Herdiana, Y., Warmadewa, I.D.G., Murtawan, H., \& Hasbi, K.M. 2013. Pendekatan Ekosistem dalam Pengelolaan Perikanan di Provinsi Nusa Tenggara Barat. Wildlife Conservation Society. Bogor. Indonesia. 52 hal.

Odum, E.P. 1971. Fundamentals of Ecology. Dasar-dasar Ekologi. (Alih Bahasa oleh : Samingan T. dan B. Srigandono). Gajah Mada University Press. Yogyakarta

Rafandi, T., Mihardja, A.T., Hernawati, Aviandhika, S., Aryawan, I.M.D.J., Saputro, E.S., Muis, A., \& Kartawijaya, T. 2017. Kajian Pemetaan Kegiatan Destructive Fishing di Provinsi Nusa Tenggara Barat. Bogor: Wildlife Conservation Society.

Rani, C., Burhanuddin, A.I. \& Atjo, A.A. 2009. Sebaran dan Keragaman Ikan Karang di Pulau Barrang Lompo: Kaitannya dengan Kondisi dan Kompleksitas Habitat. Seminar Nasional Perikanan UGM. Yogyakarta. 14 pp.

Runtuboi, F., Bawole, R., Goram, A., Wawiyai, Y., Wambraw, M., Numberi, Y.Z., Gandegoai, A., Lamahoda, P.B.E., Rumakabes, S., Laturmase, M. \& Suparlan, S., 2018. Inventarisasi Jenis Ikan Karang dan Komposisi Jenis Ikan Ekonomis Penting (Study Kasus Kampung Kornasoren, 
Saribi dan Syoribo) Pulau Numfor Kabupaten Biak Numfor. Tropical Fisheries Management Journal, 2(1):11-18.

Sale, P.F. 1991. The Ecology Of Fishes On Coral Reefs. Academic Press, Inc., San Diego, pp. 754

Sugiyono. 2005. Metode Penelitian Bisnis. CV. Alfabeta, Bandung.

Titaheluw, S.S , Kamal, M.M. \& Ernawati, Y. 2015. Hubungan Antara Ikan Chaetodontidae Dengan Bentuk Pertumbuhan Karang. Jurnal IImiah Agribisnis dan Perikanan, 8(1): 77-86

Yulianto, I., Prasetia, R., Muttaqin, E., Kartawijaya, T., Pardede, S.T., Herdiana, Y., Setiawan, F., Ardiwijaya, R.L. \& Syahrir, M. 2012. Panduan Teknis Pemantauan Ekosistem Terumbu Karang, Padang Lamun dan Mangrove. Wildlife Conservation Society. Bogor. Indonesia. 